CHAPTER FIVE

ELITE BROKERS (1934-1950)

I was the translator, the advisor, the spokesperson, the people's leader, the lottery drawer, the announcer, the teacher of Malay and Japanese language, the organizer, the leader of Seinendan, the letter composer, etc. etc.

(I.H. Doko explaining his role under the Japanese to Dutch officials after WWII, Locher 1945:4).

Indonesia's grand myth of national becoming is that the Revolution of 1945 welded together a disparate colonial patchwork. The actual history of national integration across space was much more uneven. Chapter 1 introduced two Indonesias: a central Indonesian heartland - Java, parts of Sumatra and southern Sulawesi - that owned the revolution and much other mobilizational activity before and since, and many islands in a large periphery that heard about these things from afar and were otherwise preoccupied with their own affairs. Yet Indonesia is united. How did this happen? The same chapter also began to explore the idea of mediation, and in particular of brokerage, that might lead to an answer. This chapter takes up those ideas and applies them to one particular site. The brokers who brought eastern Indonesia into the new nation came from small towns in the region. The chapter traces the biography of one of the main nationalist organizers in one small provincial town in eastern Indonesia at the time when the nation was born. He and his fellows opened doors for people wanting to pass in both directions - central government officials needing access to the region, and fellow locals wanting jobs with the new government. But rather than becoming midwives to popular democracy, they remained a small group of local elites. The politics they bequeathed to the town were factional and bureaucratic, little troubled by demands from any broader civil society.

The national myth is that the 1945 revolution worked its exhilarating magic equally everywhere. Foreigners who have read only Benedict Anderson's famous book on this episode (1972) tend to forget that he was explicitly writing only about Java. However, others have grappled with spatial heterogeneities. Audrey Kahin (1985) edited a volume exploring the differences in local leadership in towns all over the archipelago during

(C) Gerry van Klinken, 2014.

This is an open access chapter distributed under the terms of the Creative Commons Attribution-Noncommercial 3.o Unported (CC-BY-NC 3.0) License. 
the national revolution. Local variation in the history of colonial governance was among the most important explanatory factors, she concluded. More recently, Rudolf Mrázek (2010) has recorded the highly evocative words of aging urban intellectuals in Jakarta. All of them had been engaged with the revolution when they were young, but they spoke to Mrázek mainly about the intimate spaces of their youth. This chapter, too, wishes to contribute to widening the historical terrains and challenging the assumptions of a Java-centric historiography.

In 1949 Kupang's population was just 11,00o. Like many towns in this region, Kupang's economy revolved around trade and state investment. Beyond the town lay a subsistence agricultural economy. A passing car was a rarity - most people walked, a few had bicycles, and there was the occasional truck-bus heading out of town. Lower-middle class readers of the Chinese-supported broadsheets read about local incidents, agricultural statistics from neighbouring islands, and world news. Yet when the proclamation of the Republic of Indonesia in Jakarta on 17 August 1945 triggered armed youth insurrections in Java's major cities of Surabaya and Bandung, it went unremarked in Kupang. There were immediate historical reasons for this disconnect - war disasters had stunned Kupang, and Australian Allied troops took control more quickly than in Java ${ }^{1}-$ but it also had deeper roots. Kupang was part of a different Indonesia.

The indigenous local leaders who emerged in the tumultuous years spanning World War II were typically educated individuals with some organization behind them. Like the 'marginals' described by Eric Wolf (1956) in Mexico, who rose to become the ideal 'brokers' between their rural communities and the Revolutionary government via new political organizations, they learned to operate in the manipulative environment of short-term friendships and the shifting opportunities of the early independent state. The resources that they were able to deploy varied with the character of their 'home' milieu. In central Indonesia, they tended to be professional political mobilizers. Sukarno was the supreme example. In eastern Indonesia, by contrast, they came from within the colonial state, where they worked as civil servants or teachers at state schools. Popular movements occasionally emerged in eastern Indonesia too, but colonial authorities quickly suppressed them, leaving room only for local elites

1 They accepted the Japanese surrender in Timor on a warship in Kupang Bay on 11 September 1945, and afterwards faced no military problems to assuming total control. Civilian authority was in the hands of the Netherlands Indies Civil Administration (NICA) from the start. Australian soldiers were ordered to have no contact with the indigenous population, and were withdrawn on 18 March 1946 (Farram 2004:216-22). 
whose main resources came from the faraway centre, with which they collaborated. Their local politics tended to be factional rather than mobilizational. They looked to bureaucratic superiors rather than to mass constituents. From the associative form that brought it to life in and around the cities of central Indonesia, national power acquired an instrumental, even imperial form once a small collaborating elite had introduced it to the small towns of eastern Indonesia and their subsistence hinterlands. Their modalities were those of a patrimonial authority achieved by operating through the bureaucracy.

The number of indigenous government clerks rose quickly once the colonial government began to raise its developmental ambitions after the turn of the century. As elsewhere, the first native-born Kupang people to move around the vast network of modern colonial administrative oversight and social uplift were the sons of the rajas (Van Niel 196o, Sutherland 1979). They travelled along the modern shipping routes from Kupang, first to get an education - probably at the school for administrators in Makassar (Opleiding School Voor Inlandsche Ambtenaren, OSVIA, since 1910), or to various kinds of high schools in Surabaya, Yogyakarta or Batavia, and then from one colonial office to another all over the archipelago. At first most had only lower primary schooling, but the level rose as government grew more complex. Government scholarships also went to children of farmers from the early 1930s. When some of these returned to Kupang as young teachers, they positioned themselves as a new generation of local leaders. The little newspapers some of them started were vigorous in style, full of advice for advancing the colonial modernization agenda. Their politics were factional rather than mobilizational.

Elites looked to bureaucratic superiors rather than to mass constituents. Popular movements had emerged in Kupang too. But the architectural draftsman and bush lawyer Chris Pandie never recovered his zeal for tax revolts after three years in a Batavia prison in the late 1920s (Chapter 4), and the next generation of 'intellectuals' took no more interest in them. Izaak Huru Doko (1913-1985) was one of them. He was declared a national hero (pahlawan nasional) in 2006 for his contribution to the independence of a united Indonesia. He was 'one of the most consistent and steadfast of the political organizers on Timor' (Fox 1977:182). But there is irony in this notion of Doko as national hero. His generation prided itself on its local roots. They were brokers who, like the town they called their own, mediated between their local compatriots and people in distant centres. His career reflects the Faustian choices confronting the whole political class in Kupang in this transitional period. 


\section{Dressing Nicely}

Doko was born in Ledemanu village on the small island of Sabu, on 12 November 1913 (Malehere and Krenak 2006), the eighth of nine children in a subsistence household. Sabu was Christianized later than many other islands in this region (Fox 1977:160-169). His father's Sabunese name was Kitu Huru and his mother's Loni (Malehere and Krenak 2006). They were probably first generation Christians. Father was baptized with the name Benjamin, the mother's we do not know. They never left Sabu their entire lives. ${ }^{2}$ The first to enter the modern state complex was his eldest brother Paul. Although only educated at the three-year village school in Sabu, Paul's Dutch was good enough to become a government clerk. When Izaak showed promise too, Paul paid for him to continue his schooling in Kupang. ${ }^{3}$ Most of the native students there were raja's children. In 1928 he and a couple of others received government scholarships to the junior high school in Ambon (Mulo-B). In 1934, aged 21, he was among just 30 out of 300 selected to continue to the teachers college (kweekschool) at Bandung, in West Java (Boenga et al 1996). On the way he passed through that great city he had seen only in pictures - Batavia. Doko was about to become an educated, Java-experienced intellectual.

Bandung and Batavia were still abuzz with the birth of the nationalist movement a few years earlier. The outer island students picked up the buzz, but not the rebelliousness. Doko belonged to that moderate group for whom the most important thing was 'not a nation, but a lifestyle' (Henk Schulte Nordholt 2011). At the group's first public rally back in Kupang four years later, a friend named Tiboeloedji (later spelled Tibuludji) explained how Bandung had politicized them. At the student hostel for the teachers college were 208 young people from all over the archipelago. They all belonged to one of their own ethnic youth associations. 'But the Timorese did not have one, nor were they well regarded by their friends. When they realized this, they felt ashamed. They simply had to set up their own association, even if they were just two people in the hostel.' They called it 'Timorsche Jongeren,' Timorese Youth. Their purpose was to improve their Dutch by writing magazine articles, and to

2 Interview with I.H. Doko's younger brother, A.B. Doko, Kupang, 18 June 2009.

3 Paul H. Doko was killed by the Japanese in 1944 while posted in Bajawa, Flores. He was betrayed for talking too fondly about the Dutch, taken to Ende and executed. In 1948 his body was reburied in a Netherlands Indies state ceremony ('Pemakaman kembali bestuursassistent Doko,' Pandji Ra'jat, 12 October 1948). 
bring advancement to the people of their island. This modest dream, born from shame, was leagues removed from the radically non-ethnic, defiantly socialist youth ideals Sukarno had proclaimed in that same town in 1926, eight years before Doko arrived. It was not even nationalism. It was a way of being middle class that was both modern and provincial, and moreover a practical choice. Sukarno was at that moment in internal exile in Flores, a large island near Timor. The young students were grateful to the government for their scholarships and looked forward to satisfying careers under its beneficence. ${ }^{4}$

By 1937 Doko was standing in front of classes at the best school in Kupang, the Schakelschool. His decade abroad had made him a big fish in a small pond. He overflowed with zeal to improve this hot, sleepy town, and soon became known as a dashing speaker. On 7 November 1938 he married Miss Dorkas Toepoe, his assistant at a political association he had started. They were to have four sons. The activism of these ambitious young people followed the path established in Kupang by Hazaart. Like Hazaart, they too were a self-appointed avant-garde with a civilizing mission in Timor, and like him, they showed little understanding of indigenous lives. Their parents' stony yam gardens were a distant memory. Surrounded by an impoverished rural society, the elitism of the modern bureaucrat became the core value for these urban modernizers. Not for them submission to tradition and heredity.

The new graduates were welcomed back to Kupang by the first generation of politically active Timorese, all bureaucrats with experience outside Timor who had been asserting themselves since the 1920s through their Timorsch Verbond (sketches of them are in Ardhana 2005, and Kementerian Penerangan Sunda Ketjil 1953). Their Java-educated status elevated them into Kupang's better circles, while distancing them from their parents within the poor majority. The novel element for these civil servants was that they had become part-time politicians. To the claim of technical expertise, they added a political claim - that they could broker the unique culture of the locals to the metropolis, and the uplifting

\footnotetext{
4 The 3 July 1938 meeting brought together two rival Timorese organizations: (1) Doko's group of young activists called Perserikatan Kebangsaan Timor (outgrowth of Timorsche Jongeren and ideologically aligned with the older but now defunct nationalist organization Timorsch Verbond) and (2) a government-sponsored, pro-church breakaway group from the Timorsch Verbond called Perserikatan Timor led by the government clerk Christian Frans. The younger ones wanted the Raja of Amarasi, H.A. Koroh, for the Volksraad. The local government eventually agreed to sponsor the more 'cooperative' C. Frans, but nothing further had been done when the Japanese intervened (see the excellent institutional account in Ardhana 2005:259-79).
} 
mission of the metropolis to the locals. The latter claim did not erupt from an outraged sense of social injustice, but expressed their proud appropriation of a colonial vision of citizenship in any future independent Netherlands Indies - which was that it would be essentially ethnic.

The association Timorsch Verbond, run by the older generation, long enjoyed financial support from the expansive Tjiong Koen Siong and other Chinese businesspeople. The latter no doubt hoped they were nurturing a new middle class with purchasing power. When visiting Kupang in June 1932, for example, Timorsch Verbond members from the big cities further west - Makassar, Surabaya, Bandung, Batavia - were careful to maintain their distance from the kampong. They stayed in the Chinese clan house Lok Seng Hwe, drove around in a car supplied by Tjiong Koen Siong instead of walking like everyone else, and held a public meeting to raise support in his downtown movie theatre. Beneath the chummy stylishness, rivalry between various elite Timorese factions was often bitter. Each clique had its organization and its local gossip newspaper. Tjermin Timoer ('Mirror of Timor') let fly at the Doko crowd (associated with Tjinta Kebenaran, 'Love of Truth') by revealing the elite connections mentioned above. The wider public cared no more for them than they for it, the paper went on sarcastically. Ordinary Kupang folk got more excited about the visit of a warship, submarine, airplane, or the Governor-General than about the Timorsch Verbond. Any complaints these young elites had about the situation in Timor were those of outsiders, it added as the final stab. ${ }^{5}$

Theirs, indeed, were the politics of the ambitious official. They exposed abuses, corruption, inefficiency, and special privileges, but built no social movements. They took no political risks. When the Resident banned his civil servants from joining the Timorsch Verbond in 1930, the organization quickly sagged (Ardhana 2005:273-4). In 1938, however, Batavia once more opened the door a crack to local politics by agreeing to increase the number of native delegates to the colonial proto-parliament, the Volksraad. Kupang wanted to raise a constituency for a member from Timor. The 25-year old Doko told a well-attended meeting in Tjiong Koen Siong's movie theatre on 3 July 1938 that 'tomorrow' belonged to the youth. The first essential task for the younger generation was to establish localist credentials. Their claims of belonging were self-conscious to the point of artificiality. A.Z. Palindih, the young editor of one of the local newspapers,

\footnotetext{
5 Tjermin Timoer, June-August 1932.
} 
whose father, judging by his name, was West Sumatran, introduced himself as 'a Timorese young person because my mother is from Timor.' ${ }^{6} \mathrm{He}$ said he felt moved by the native sasongko music played during the interval. Palindih became chair of the committee to lobby for the Volksraad seat. All the candidates they had in mind were in government service. But the young ones felt the older guard, such as the aristocrat J.W. Amalo (who worked at the state oil company in Surabaya) and C. Frans (an official at the Resident's office), had 'already become European' and had moreover spent too much of their lives in Java to be credible in Timor.

However, the younger generation, too, had developed good dress sense in Java. Fashionable suits and shirts made of 'gabardine, palmbeach or poplin' or even of Parisian silk could be ordered from the tailor at Yong Sen's shop on Pantjoeran Street (this establishment also took quality photographic portraits, and sold patent medicines - Figure 20). Clothing expressed their new identities - modern, urban, and as far removed from the Timorese sarong as possible. Maybe they had even tried the expensive Portuguese wine imported through Dili, best enjoyed with genuine Dutch cheese, both available at Koepang Stores. Gramophones and other 'modern goods' - the desirable symbols of upward social mobility - were sold at Toko Bombaij Koepang.

None of this made it easy to claim they represented the common good. Yet they desperately wanted to be intellectuals with a serious mission. 'So many youths still think this is all about dressing nicely,' the same Palindih warned gravely at the July rally. A common enthusiasm for progress would, he hoped, bridge the social chasm that now separated them from the poor. Participants called on each other to be inspired (semangat), to build schools and cooperatives all over the Timor residency. Like the New Order engineers who were later to transform the technical wizardry of the Palapa satellite system into a top-down discourse of nation-building (Barker 2005), these young enthusiasts gave a political meaning to the organizational techniques they were bringing to Kupang. But the mission civilisatrice was lonely work. Palindih observed soon afterwards in an op-ed piece in his paper that in Timor the labouring poor showed a regrettable lack of interest in the improvement plans laid before them by the intellectuals (something Tjermin Timoer had already noted before him):

\footnotetext{
6 'KT mengadakan openbare vergadering,' Tjinta Kebenaran, July 1938. Palindih was editor at Obor Masjarakat, and previously at Pewarta Timoer in 1936. After the war he became a journalist in Bandung.
} 


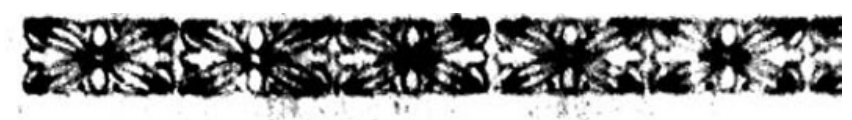

\section{KABAR PENTING BOE, 2.1}

Terimalah sectala keperioean I oeat

\section{YONG SENG}

\section{Pantjoeranstrant Timoer Kc}

Disitoe dap at segala barang bagoes, roet zaman, ", Maleset."

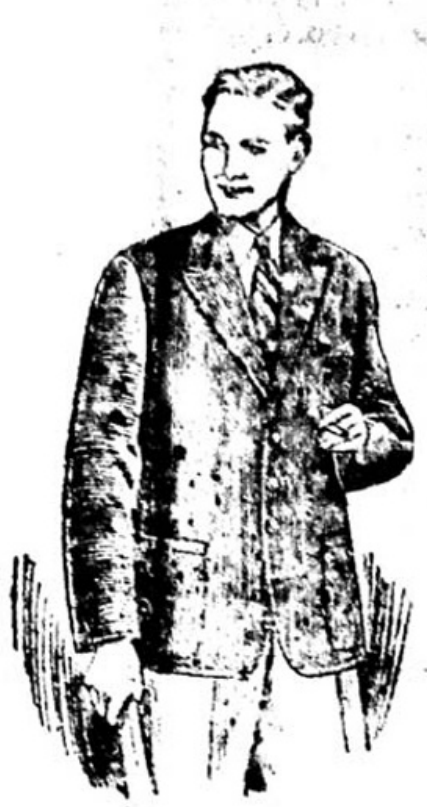

pothet. Membc

- ketiji buleh di djoeal segala membekin bi boleh pangell

TOEKANG DJATT. kaian Taean-: gueng bagoes broek, Jas, pa beach. Popli dan betdjenis nja. dan anai

Teriebilh. at moer. Sérimo Kebaja renda tra; Voal, Fg dak wang:. $A$ Barang Lux: alpaccatoelen dan cbat oba theek Koepai

Silahkan m

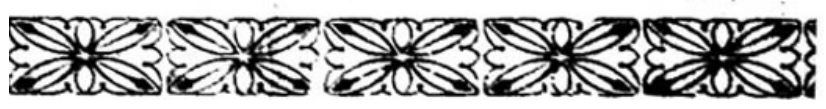

Figure 20. Advertisement in Fadjar (Kupang), May 1933. 
When we speak of intellectuals here we mean firstly those among us with a Western education and secondly those who have [native] intelligence. ... Ordinary folk come to these intellectuals to tell them things and then go home to tell others about it. The intellectuals give leadership to the impoverished people or the masses. Meanwhile the masses with the strength of their bodies, with their work, give sustenance to the intellectuals. ... If we now observe society in Timor, we can see that there is no such relationship between intellectuals and people. The intellectuals have not the slightest interest in their own people; indeed they sometimes despise them. Similarly the people sometimes do not give the intellectuals a thought. This situation is not good! ... There is so much we should be doing for the people, such as eliminating illiteracy, health training, education, and so on, and all of this can be done together with the government. ... It is crystal clear that a deep and wide chasm separates the two. ${ }^{7}$

The emerging elite's disconnect with any popular constituency came back to haunt it soon afterwards. Feeling little pressure to act, the government dragged its feet on appointing Frans to the Volksraad. Soon the money from local elites dried up, and the association's energy ebbed away. Doko continued to teach. He and the other young Rotenese and Sabunese intellectuals went back to paying deference to their 'already European' elder Christian Frans, who occasionally pushed some money their way. Doko wrote articles for the church newspaper Soeloeh Indjil, run by a Dutch reverend, and for Pemimpin Raiat, the official Residency broadsheet led by Frans (Locher 1945).

The gap Palindih worried about was real. Kupang's better broadsheets often reported on the benighted lot of peasants in the town's hinterland, who were served justice by ignorant rajas instead of professional magistrates and who were unable to understand proceedings because they had no Malay. ${ }^{8}$ But this was for these intellectuals a social problem, not a political one. On the whole their small town papers breathed colonial tranquillity. The state apparatus to them was strict but benevolent. Kupang's rituals of church, office gossip, and occasional dances at weddings were comfortable. Their papers convey no nostalgia for their ancestors' villages.

\section{Golden Boy}

As for so many of his generation all over Indonesia, the Japanese occupation gave Doko his first experience of real politics, and of blood. The

7 Obor Masjarakat, November 1938.

8 E.g. Tjinta Kebenaran, 20 November 1935, quoted at the head of Chapter 4, and Pewarta Timoer, 6 December 1939. 
consequences of earlier choices now came into sharp focus. He was 28 years old in 1942, and had a 'bright personality' (Locher 1945). The town's airport had made Kupang an international transit point since 1940; it now became a strategic asset for the Japanese. When war broke out, Doko helped out at the Red Cross emergency hospital set up in Naikoten, Raja Kupang's home south of the town. Soon afterwards he evacuated to Tabun, a village just west of Kupang, where his wife was already. ${ }^{9}$ Allied troops had landed to halt the Japanese advance, but they were forced to retreat and made a desperate last stand at Babao about $30 \mathrm{~km}$ outside Kupang in February 1942 (Farram 2004:167-9). The Japanese used Penfui as their base for continuing the bombing raids on Darwin that they had first launched from aircraft carriers. Kupang's residents feared retaliatory bombs and fled to the safety of the hills. The economy came to a halt. Doko went often to Kupang to barter for daily necessities and attend church.

The Japanese were ignorant and under-resourced in the vast archipelago. Whereas Sumatra and Java - the heartlands - were occupied by armies (respectively the 25th Army and the 16th Army), the periphery was administered by the Imperial Japanese Navy. By contrast with the mobilizational military regimes in the heartlands, the aim in the (in parts) resource-rich but population-poor islands from Kalimantan to the Sunda Islands was to annex the region permanently while avoiding political mobilization. Japanese civilian bureaucrats were brought in, who tried as much as possible to make use of native administrators (Post et al 2010:7286). They needed loyal local allies to be their eyes and hands without triggering revolts. The Japanese doctor who had come to live in the Dutch reverend's house befriended Doko and introduced him to the new regime. With their coercive resources kept largely behind their backs, they exercised power in manipulative and even seductive ways. The young Timorese intellectuals were ambitious, experts in organization, and good public speakers. In return for their support, the Japanese offered these invaluable brokers a status leap over the Dutch and the aristocrats, unprecedented public exposure, and escape from the inevitable shortages to come.

They made Doko editor of a weekly propaganda newspaper called Timoer-Sjoeho. In June 1942, his paper began telling people it was safe to come back to Kupang and urging them to do so. Darwin, the feared source of long-range bombers, was a long way away and being hammered every

9 Locher 1945. There had earlier been an emergency hospital in the Societeit (Soh and Indrayana 2008:95). 
day. ${ }^{10}$ In August the tone became threatening - those who refused to return to the markets were hoping America would win the war. ${ }^{11}$ People were told to turn in furniture, clothing, office equipment and of course guns the Dutch may have left behind. They should plant cotton for Japanese uniforms. But Doko's persuasive powers had their limits. In September the town was still deserted, and in November 1942 residents were being urged to seek shelter from bombing raids now coming from Darwin. Many hungry children were arrested in December for stealing food. Timoer-Sjoeho revealed how quickly shortages had become serious when it reported a year after the invasion that 5,000 people had turned up hoping to buy one of the 1,200 pieces of cloth in a special sale in the Chinese shops by the beach. In September 1943, lucky people with ration cards had one day to replace one of their bicycle tires with a new one. Another one-day sale of rationed cloth, shoes, and umbrellas in three designated places followed in January $1944 .^{12}$ Government offices had been evacuated to temporary accommodation in Bakunase, in the hills four kilometres south of town. The authorities squeezed the Chinese traders for money and war contributions in kind (leather; donations at feasts). Kupang was reported to have 'contributed' 400,00o Dutch guilders to the Japanese war effort by April $1945 \cdot{ }^{13}$ But the Japanese also needed the Chinese to keep the economy turning over, and there was money to be made from scarcity. In March 1944 Tjoei Tek Giok won a contract valued at 89 rupiahs a month - a substantial amount even in inflationary times - to be the town's sole supplier of palm wine for a year (Pak Laru). ${ }^{14}$

C. Frans, Doko's immediate superior and one of Kupang's best-known personalities, was the Timorese face on the Japanese occupation. He had long been an admirer of Germany's energy, though not of Hitler, and he became an enthusiastic collaborator with Germany's Asian ally (Locher 1945). In January 1943 his office started showing Japanese war propaganda films in the very movie theatre where a few years earlier he and Doko had debated who should be the Timorese Volksraad candidate. However, factionalism was rife. This was partly a consequence of the poor quality of the Japanese staff, who in the area controlled by the navy turned out to be

\footnotetext{
10 'Djangan koeatir bom kapal terbang,' Timoer-Sjoeho, 18 June 1942.

11 'Sadarlah!' Timoer Sjoeho, 6 August 1942.

12 Timoer-Sjoeho, 27 January 1944.

13 Borneo Shimboen, 18 April 1945. The figures seem incredible.

14 Timoer Sjoeho, 9 March 1944. This is possibly a mis-spelled reference to Tjioe Tek Giok, who was to become the first ethnic Chinese Christian in Kupang in the 1950 s (see Chapter 11).
} 
'inefficient, incompetent, and unprofessional.' It was even more a consequence of naval dissatisfaction with the supremacy civilian politicians in Japan nominally enjoyed over navy affairs (Post et al 2010:86, 78). Each Timorese staff member had his Japanese patron. In May 1943, Frans was murdered by a branch of the Japanese intelligence service. ${ }^{15}$ The problem went back to pre-war rivalries, between the Timorsch Verbond and a 1924 breakaway known as Perserikatan Timor. Allegations from other Timorese that Frans had been less than loyal appear to have played a role. Frans had been badmouthed to the Japanese by Frans Djami, the radical journalist of the late 193os (see Chapter 4). Soon afterwards Djami was in turn tortured to death during interrogations by the Japanese police over the Frans murder (Farram 2004:194). Frans' murder was a huge shock to the collaborating elite. Apparently not even the most pro-Japanese of Timorese was safe. Doko later told Dutch interrogators he had been subject to similar intrigues, and he mentioned several names (Locher 1945).

Doko now replaced Frans as head of the Social Information Department, in charge of propaganda. Manipulating affections was core business in a wide range of activities. Besides the newspaper, which had moved to Bakunase (Djeki 1980:35-6), there were propaganda films showing in Tjiong Koen Siong's cinema, and he was in charge of education, religious affairs, and health. He organized the churches into a state-controlled ecumenical body chaired by the Raja of Kupang, Nicolaas Nisnoni (Locher 1945:9). He turned church schools into state ones (Locher 1945:9), and replaced Dutch in them with Malay (Ardhana 2005:321). But few schools were running - the first primary school in Kupang did not reopen until September 1942, in a private home. Nevertheless, the patronage he had at his disposal made him popular among other educated people in Kupang needing a job. Like the father (bapak) who provided the idiom for Javanese leadership roles from the schoolteacher through the military commander to the president (Shiraishi 1997), Doko became a patron particularly for the Sabunese.

The Japanese rewarded him handsomely for his services. He was named 'People's Leader' (Pemimpin Raiat) and appointed to the provincial council, on a generous annual salary equivalent to 1,200 Netherlands guilders. They gave him 'envelopes' and packets of cigarettes for organizing feasts, sports competitions, night markets, theatre performances (the latter

\footnotetext{
15 Its name was said to be Otori (Farram 2004:194), but no such service is mentioned in Post et al (2010). Was Otori perhaps the name of an intelligence officer in the shadowy agency Hana Kikan?
} 
producing sometimes hilarious local scripts). The Minseibu were bad organizers, Doko said afterwards. They partied nearly every night at their base at Airnona south of the town centre, and had little idea of what was going on in Timor (Locher 1945:17, appendix). He told Dutch interrogators that his Japanese boss at Minseibu, Captain Yuasa, regarded him as his 'golden child' (anak emas). He was a 'jack-of-all-trades' (manusje van alles):

[I was] the translator, the advisor, the spokesperson, the people's leader, the lottery drawer, the announcer, the teacher of Malay and Japanese language, the organizer, the leader of Seinendan, the letter composer, etc. etc. (Locher 1945:4).

Public rituals were central to the Japanese effort at building power. Allied air attacks escalated with a huge raid on 10 April 1943, followed by another big one on 15June 1943. This one led the Japanese to evacuate their offices in Kupang town to join the refugees already at Bakunase. Doko organized frequent all-day rallies on a parade ground the Japanese had cleared at Bakunase. A little larger than a tennis court, it was located at Airnona, next to Raja Nisnoni's royal well. Today it is built over by housing. This was the beginning of the popular mobilization that continued into the postwar period. They were compulsory for all civil servants and school children, much as such rituals had been under the Dutch and as they remain today. His first major appearance was at the Meiji Emperor's birthday celebration on 3 November $1943 .{ }^{16}$ On the dais decorated with flowers, the rajas of southern Timor sat in their ikat finery next to Japanese navy officers in white. Most prominent of the rajas was the energetic H.A. Koroh, Raja of Amarasi just south of Kupang (1904-1951) (Doko 1981a). He had been invested acting raja of Kupang as well, because the incumbent, Nicolaas Nisnoni, was too old and pro-Dutch to be useful (Ardhana 2005:320). The programme for these rallies varied little. Bow to the flag, then sing the Japanese national anthem Kimigayo: 'May your reign/ Continue for a thousand, eight thousand generations/ Until the pebbles/ Grow into boulders/ Lush with moss.' Speeches follow by the local deputy head of government, the Ken Kanrikan, equivalent to the Dutch Assistant Resident), and by Doko. ${ }^{17}$ Doko expressed gratitude to the heroic Japanese

16 'IH Doko, Pidato Pemboekaan Oepatjara Meizi Setsu,' Timoer-Sjoeho, 4 November 1943 .

17 The Ken Kanrikan was Kokobun Tojozo until January 1944, when he was replaced by Tomida Hikoziro (Timoer-Sjoeho, 27 January 1944). 
and urged people to work hard for a prosperous Greater East Asia. ${ }^{18}$ Primary school children sing Japanese martial songs ending in a rowdy 'Banzai!' - then games and sports, exactly as for the Dutch queen's birthday celebrations earlier. Football might pit old against young civil servants, followed by young locals against outsiders. Food is served to the invited civil servants between matches - including eggs and fruit courtesy of the raja's rural subjects. Prizes and medals follow for deserving people, and on at least one occasion the drawing of a government lottery. More speeches of gratitude and admonition, then another flag ceremony plus mournful Kimigayo, and some time after dark the little field was deserted. ${ }^{19}$

Recruiting bodies for the occupier's war effort was another part of the broker's role. On 11 February 1944, at the celebration of Japanese national foundation day (Kigen-setsu), Doko announced a new youth organization, Seinendan. This multi-purpose work force came late to Timor - it had been operating elsewhere for nearly a year - but soon branches were formed also in the smaller up-country towns of Timor, and in Ende on Flores (which also had a women's Seinendan). Doko was ex officio second in command in Kupang, under a navy daidanco named Tonita (Widiyatmika 2007:342). One of their most important functions was to bury the increasing number of dead from Allied bombing raids that were now targeting every large and small town of eastern Indonesia. Doko travelled all over Timor to train them (Ardhana 2005:322). ${ }^{20}$ The ageing raja Koroh was an enthusiastic recruiter for Heiho units, more militarized than Seinendan but still unarmed. Women joined Heiho too, and more recruits were brought from Java. The raja also recruited romusha forced labourers. They dug defence ditches to prepare for the Allied invasion that the military feared (Ardhana 2005:320, Widiyatmika 2007:342) ${ }^{21}$ In the first half of April 1944 wave after wave of Mitchell bombers struck all over Timor and caused big fires in Kupang. ${ }^{22}$ In June Doko travelled to his

18 Similar speeches followed on 8 December 1943, to commemorate the formation of Greater East Asia, and on 20 February 1944 in honour of the Japanese soldiers who had landed on Timor's coast exactly two years earlier ('Perajaan 8 Desember 26o3, Hari Pembentoekan Asia Timoer Raja,' Timoer-Sjoeho, 18 December 1943; Timoer-Sjoeho, 24 February 1944).

19 Timoer-Sjoeho, 17 February 1944; 24 February 1944.

20 He later claimed it only ever had 180 members and did mainly sports and a weekly military exercise with wooden bayonets (Locher 1945:3-4).

21 Widiyatmiko is incorrect to date the formation of the local Seinendan to April 1943.

22 Oetoesan Penjoeloeh, 11 April 1944. More bombardments of Kupang and other towns in Timor are mentioned in this Allied newspaper: Oetoesan Penjoeloeh, 2 June 1944 and Penjoeloeh, 13 October 1944. 
native island Sabu to recruit forced labour for an agricultural project south of Kupang. Earlier, Koroh had begun supplying 'comfort women' to the thousands of Japanese soldiers stationed in Timor (Doko 1981a:62). Shocked locals renamed the Bakunase area 'Sodom and Gomorrah' for its brothels (Netti and Itta 1997:80). Hotel staff and restaurant waiters often received food in exchange for sexual favours (Netti and Itta 1997:81). By 1944 the war was going badly. An Allied blockade stopped food supplies from Java. The town had grown too large to live off the land, and anyway the Japanese requisitioned all surplus agricultural production (Locher 1945). Kupang residents later recalled the hungry end of 1944 as 'the year of tears' (Netti and Itta 1997:81).

In 1945 the town became symbolically Indonesian through the raising of the red-and-white flag. Where central authorities in Japan had ordered the 16th Army in the Javanese heartlands to respond to political pressure with promises of independence, they had never felt moved to give similar instructions to the Imperial Japanese Navy running eastern Indonesia. But by July 1945 Japan was nearly on its knees and ready to make belated concessions even in remote areas. At the ceremony on 8 July it did insist on the Japanese flag flying next to the Indonesian one. Doko and Raja Koroh were prominent guests. ${ }^{23}$ In any case, as Doko later told his Dutch interrogator, he had no intention of subjecting Timor to Java. When the Japanese, thinking they were yielding to Indonesian national pride, offered to sponsor a commemoration in Kupang in honour of Diponegoro, hero of the Java War of 1825-1830, Doko told them 'the Timorese people do not know who Diponegoro is' (Locher 1945:10).

When at last it was all over and the Japanese were required to maintain the peace for the few weeks it took the Allies to land in Kupang, they put Doko in charge of the town, together with two other local prominents named Tom Pello and the medical doctor A. Gabeler (Ardhana 2005:3478). The Allies arrived on 11 September and relieved local worries that the Japanese might engage in irrational murder in the interval (Netti and Itta 1997:84). No one worried about a nationalist youth uprising, and there was none. The first correspondent to walk around Kupang after the Allied landing, six weeks after war's end, was shocked at the destruction. The heart of town lay in ruins, its population evacuated to the Bakunase

23 Doko later claimed the flag-raising took place on 29 April 1945 (Doko 1981b:81-3). The correct date is in Doko's interrogation report of November 1945, with his speech (Locher 1945) (see also Netti 1997:83). Perhaps Doko had also been present at the first flag-raising in Makassar on 29 April 1945 (Post et al 2010:85). 
coconut plantations, where even 'aristocrats and the rich' lived in little huts and ate only what they could grow. Even a year later a visitor from Ambon said the town was worse off than his own bombed-out city: 'the place where Kupang town used to be now looks just like a jungle.' Here and there people had built houses and offices from temporary materials. ${ }^{24}$ Allied soldiers brought in loads of coins to restart the economy. They could find no beer, and no spare light bulb for the film projector. Many bridges remained unrepaired for over a decade.

More shocking to the first correspondent (identified only as ' $\mathrm{K}$. K.') was the readiness of the elite to collaborate with the occupier. Seeing this representative of the new master, people sitting passively along the road told him or her what it had been like during the Japanese interregnum: "Timor Kupang folk forgot their own people, so long as they were given as good a position as possible. ${ }^{25} \mathrm{~K}$.K. was especially upset to hear of the factional betrayals, and the spying for money that claimed so many lives.

\section{More Regime Changes}

When the Allies landed, Doko was nearly 33 and already facing his second regime change. Two more were to follow - in 1950 and 1966 - and he navigated each with consummate skill. Provincial politicians with ambitions learn to be survivors. He was one of many the Dutch arrested for possible crimes committed as collaborators. But Allied intelligence cleared him of war crimes and, to avoid 'embittering' a gifted man (who had moreover received many letters of support from educated Sabunese), they put him to work organizing the repatriation of displaced persons in Timor (Locher 1945). There were large numbers of Javanese evacuees but no transport back to Java. These former forced labourers and prisoners of war had in the meantime to be fed and housed.

The returning Dutch administrators reported in April 1946 that they had no concerns about security in Kupang, but hoped shortages would not lead to dissatisfaction (Wal 1982:IV, 82-85). The revolutionary Republic of Indonesia largely controlled the Javanese heartland of the archipelago and parts of Sumatra. The Dutch Lieutenant Governor General Van Mook began seeking out local elites in the regions once more under Dutch

24 'Perdjalanan ke Ambon,' Soeloeh Rajat, 7 September 1946.

25 '[B] angsa T Koepang sendiri loepa akan mengingatkan bangsanja sendiri asal sadja mereka itoe dikasih kedoedoekan sepenoeh-penoehnja' ('Riwajat Pendoedoek Koepang dibawah Tindasan Djepang,' by K.K, Penjoeloeh, 22 November 1945). 
control, hoping to form a government with some traditional legitimacy. He did this by elaborating the federal structure inherent in the neo-traditionalist indirect rule approach from before the war (Yong Mun Cheong 1982). A well-supported conference of local rajas and others from the periphery, which he sponsored in the Sulawesi town of Malino in July 1946, established what was to become the most successful of the federal units, the State of East Indonesia (Negara Indonesia Timor, NIT).

However, those elites in eastern Indonesia who had invested the most prestige in the Japanese now feared downward mobility; they looked instead to the Republic. Doko formed a cautiously pro-Republican little group in Kupang with some links to Jakarta, called Partai Demokrasi Indonesia (Timor). It claimed to be the party of the 'intellectuals who are Indonesians in Timor... and can be taken as the voice of all the people of Timor.'26 Someone in a visiting Dutch delegation thought several of its members held 'fascist' views (Ardhana 2005:356). Sensitive to the violent image the Republic had outside Java, his party told a Makassar newspaper it was 'not anti-nationalism,' but it was 'anti-banditism.' They didn't like being called 'black Dutchmen or natives,' but were 'Indonesians.' They favoured an independent Indonesia based on federalism. ${ }^{27}$ In reality, though, the party's immediate aim was largely factional. As before the war, the differences revolved around claims of local authenticity. Bureaucrats resident in Kupang tried to pre-empt a group of Timorese resident in far-away Jakarta from representing Timor in the embryonic NIT. ${ }^{28}$ The rajas of Timor appointed an island parliament in October 1946 (without elections), and Doko became the member for Kupang. He travelled to Denpasar in December 1946 to take part in another conference called by Van Mook, whose purpose was to make NIT a reality. ${ }^{29}$ NIT was organized fairly consultatively into a loose, complex structure, a federation within a federation. The Dutch still ruled Timor, itself another federation, through the rajas.

By the end of 1947 Doko had become a member of the NIT parliament in Makassar, in the nationalist fraction. ${ }^{30}$ From now on he only made

\footnotetext{
26 '[G]olongan tjendekiawan (intellectueel) bangsa Indonesia di Timoer... dapat dianggap sebagai soeara ra'jat Timor segenapnja' ('Mosi,' Soember Penerangan, 15 July 1946).

27 'Bekerdja bersama-sama', Soember Penerangan, 2 July 1946.

28 'Pendirian,' Pandji Ra'jat 16-7-1946; Pandji Ra'jat, 23 July 1946.

29 Netti and Itta 1997:88-9; Pandji Rajat, 6 December 1946, 10 December 1946, 18 December 1946. They stayed in Denpasar for months (Pandji Rajat, 4 February 1947).

30 Pelita Rakjat, 27 November 1947, quotes Doko as a member of NIT parliament, in the fraksi nasional, urging federation by 1 January 1949. The other fractions were labelled 'democratic' and 'progressive.'
} 
visits to Kupang. Soon afterwards he was in the NIT cabinet, as Junior Minister for Information. Early in 1949 he reached the peak of his career as Information Minister (Figure 21). He now belonged to Indonesia's busy and highly mobile political elite, flying on DC-3 airliners across the archipelago. The vital action took place far from Kupang, at a whirl of meetings in more important towns to the west, in the United Nations, and even in the Netherlands. Doko's book History of the Independence Struggle in East Nusa Tenggara (1981b), standard fare for history students in Timor even today, is in reality his travel diary along the network of modern transport used by the nation's highly mobile elites. His peasant-born generation of bureaucrat-politicians had displaced the Dutch administrators and the rajas as the official interlocutors for the backward east. But whereas politicians from the heartlands of Indonesia were vocal at these meetings and could claim to speak on behalf of a public brought together through associational forms of power, those from the periphery could hardly claim to carry a message from any popular constituency. They kept a low profile, realizing they were there mainly to pass the message back to their regions once all had been decided.

Doko's politics had not succeeded in stirring much grassroots feeling in Kupang. Elite rivals, judging the Dutch to be back for good, took up the sponsored Airnona rally he had invented and turned it against him. The

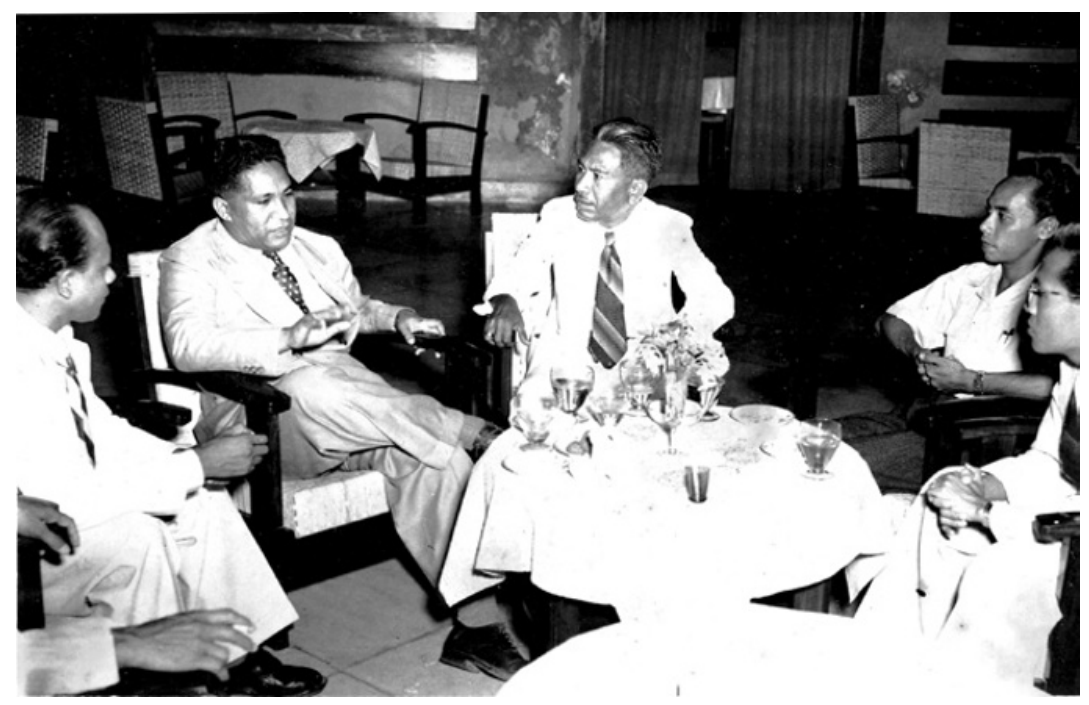

Figure 21. I.H. Doko as NIT cabinet minister (photo courtesy Mr. Leopold Nisnoni). 
first post-war rally occurred on 23 March 1947. Indo-European civil servants, ex-soldiers from Ambon and elsewhere who had been prisoners of war in Timor, and some rajas, livened up by a bamboo flute orchestra, loudly rejected the Republic. Doko had been a 'leading propagandist under the Japanese,' they said. ${ }^{31}$ The Dutch resident C.W. Schuller gladly paid the bill (Ardhana 2005:379). His secretary Willem Versluys wrote in January 1947 that the Timorese feared the spread of Javanese, Islamic influence to Timor (Farram 2004:229). Indeed, few people wore the Indonesian national red-and-white even though there was no ban on it.

Now based hundreds of kilometres away in NIT's capital Makassar, Doko sent his comrade E.R. Herewila to open an Information office in Kupang in February 1948. The establishment of NIT did not preclude republican subversion, and Doko was by no means the only senior NIT official to play both sides. Herewila organized a counter-rally at the Airnona field on 23 December 1948, to protest against Dutch military aggression in the Republic (Doko 1981b:162, Netti and Itta 1997:93). But like the pro-Dutch rally of March 1947, this one too seemed to attract more outsiders than native Kupang denizens. Javanese ex-Heiho and ex-forced labourers who were still waiting for transport home found it interesting. The only locals to organize some republican events were a nationalist student group and some members of the Muslim minority. Anyway, the occasional rally on the small field at Airnona on the southern outskirts of town hardly constituted politics of the kind that stirred Java during this era. The Dutch authorities in April 1946 reported to their superiors that the political situation in Kupang was 'without problems,' and Kupang hardly occurs in the Dutch reporting again after that (Wal 1982:IV, 82-85). The first Indonesian governor of the Lesser Sunda Islands summed up the Japanese occupation and revolutionary period in the eastern archipelago in the words: 'the political scene had been quiet' (Reksodihardjo 1960 [1957]:31). The brokers of Doko's generation had been unable to make a success of any of the top-down attempts to generate associational power in Kupang from afar, whether sponsored by the Japanese, the Dutch, or the Republic.

On 29 September 1949, the Resident solemnly handed over some of his powers to a Timorese council of rajas under Raja Koroh. In October and

31 Pro-Dutch rajas in South Sulawesi later also protested against him ('Pengangkatan I H Doko Diperotes,' Pelita Rakjat, 27 January 1948; Pelita Rakjat, 28 January 1948; 'Protes dari Radja2 di Soelawesi Selatan,' Pelita Rakjat, 29 January 1949). But Doko never pushed the political envelope. In May 1948 he resigned from the nationalist organization Gabungan Perdjuangan Kemerdekaan Indonesia (GAPKI) because it rejected NIT's federalist standpoint (Pelita Rakjat, 25 May 1948). 
November 1949 a Timorese parliament was chosen through local elections, and on 27 December, as elsewhere around the region, the Dutch flag was lowered in Kupang.

That Timor still did not belong to the Republic even after the flag had been raised was evident from the cool reactions to the Indonesian military operation soon afterwards that brought troops to the island. All the federal territories under Dutch control had units of the colonial but largely indigenous armed forces KNIL. A revolt against the Republic from among KNIL troops in Ambon early in 1950 threatened to spread to Kupang. The dispatch of troops is the most basic and instrumental form of power-at-adistance, but as the Japanese had also found, Indonesia could achieve little with armed force alone. The Indonesian army approached Kupang cautiously. Doko's Information Department in Makassar facilitated a preliminary visit by two officers to size up the situation and address a sceptical public. Captain Andi Jusuf, one of the two, then travelled into the interior of Timor as far as the Portuguese Timor border. In May $195^{\circ}$ another military delegation, led by Captain C. Kodiowa, addressed a public meeting at Kupang's famous cinema (Netti and Itta 1997:96-9). When the first ships arrived on 25 May 1950, they pulled in at night. On board were shock troops from two battalions of the Siliwangi division in West Java, commanded respectively by Major Soekendro and Lt. Col. R.A. Kosasih (Farram 2004:285, Tari 1972:I, 32). The next day they held a public parade at Kupang's military base at Oeba, together with those KNIL troops, under Lt. Y.D. Faah, who were prepared to transfer to the republican armed forces APRIS (Netti and Itta 1997:99). ${ }^{32}$ No violence erupted during this handover, but months of tension ensued with Kupang's local population. Allegations of misbehaviour by the Indonesian troops survived in Indonesian print even into the New Order (Doko 1981a:61). The newly recruited Timorese troops, a company under (by then) Captain Faah and under the overall command of Siliwangi officer R.A. Kosasih, were later that year deployed against their former KNIL comrades in Ambon, some of whom were also from Timor. ${ }^{33}$ Among Faah's men was the future governor of East Nusa Tenggara, Lt El Tari (who had, however, been with the republican forces since the 1940s). ${ }^{34}$

32 APRIS were the Armed Forces of the United States of Indonesia (Angkatan Perang Republik Indonesia Serikat).

33 Interview Hendrikus Ataupah, Kupang, 11 June 2009; Buli et al 1977-78:133.

34 APRIS troops spread out over the large neighbouring island of Flores at the same time. Something of the atmosphere surrounding this military occupation is found in the 
Doko had gone on to become Education Minister within NIT in March 1950, but the federation's days were numbered. NIT dissolved itself into the United States of Indonesia on 17 August 1950, as had been Doko's desire. His remaining career was spent building up the education system in his part of the country. Yet most of Kupang's elite had never had a particular problem with Dutch colonialism. After the Japanese interlude, schools went back to teaching in Dutch, until the late 1950s. Leo Nisnoni, grandson of Raja Nicolaas Nisnoni, only forced himself to learn Indonesian at the age of 27 , when he became a civil servant in 1963 . He always spoke Dutch with his family. ${ }^{35}$

\section{Liaison Brokers}

In the first part of the period spanning decolonization, between the 1930 s and the early 1950s, Kupang was a quiet little town that mainly serviced its agricultural hinterland in the eastern part of the archipelago. Far away from the nearest major city, Makassar, it was a typical Middle Indonesian small town. By contrast with the vigorous modern social movements in the heartlands that emerged from a dense network of substantial cities, politics in Kupang were confined to the factional fights among a handful of Java-educated civil servants. The resources these bureaucrats were able to deploy in order to develop power within the town were limited by an elitist lifestyle that set them apart from the great majority of the kampong poor, and by their professional obligations to government service. At the same time, the access they had to decision-making processes in the metropolis was equally limited by the insignificance of the constituency they could bring to the table.

Catholic mission journal Ende-Post. Just before they arrived, the editor warned his clerical readers not to imperil the mission by an ill-chosen word or a 'condescending attitude' (dedaine houding) towards the new authorities. A priest named Van Dijk failed to heed the warning. Coming on his horse upon a band of young Islamic men enthusiastically waving red-and-white flags, he shouted at them in his usual manner for blocking the road. The youths claimed to be 'soldiers'; this was an insult to the new nation. They man-handled the priest, threatened to kill him, and days later handed him over to a military officer in uniform, who released him. Even a year later the mission thought it necessary to repeat its warning against the use of colonial-sounding expressions to describe themselves such as 'native sister' (inlandsche zuster), 'New Guinea,' 'Batavia, 'natives' (inlanders), or 'sir' (tuan) ('Aanpassing,' Ende-Post no. 27, March 1950, p. 3; 'P. v. Dijk schrijft over zijn molestering op 22 juni,' Ende-Post no. 30, July 195 o pp. 2-3; 'Pedanda Bali,' Ende-Post no. 36, March 1951, pp 1-2).

35 Interview with Leopold Nisnoni, Kupang, 27 May 2009. 
Their resources were those of the 'liaison broker' (Gould and Fernandez 1989), who stands largely outside both the groups they are trying to connect, indeed whose prestige derives from the fact that the communication between them is limited to that which the broker conveys (see Chapter 1). This made them patrons to the tiny indigenous middle class in Kupang, a bringer of jobs, scholarships, and perhaps some protection for their upwardly mobile young people. For metropolitan interests needing to extract resources from the town and its surrounding hinterland (such as taxes, or at least an agreement not to revolt), they offered to translate demands downwards and explain problems upwards. As a side benefit, they earned substantial commissions.

Elitist politics like these seem to have been common in all the small towns of Middle Indonesia. They were those of a small, factionalized clique of liaison brokers. Middle classes were too tiny and culturally remote from the metropolis to make their own demands clear. All over Indonesia, national power came to the regions in mediated ways. Audrey Kahin once observed that the national leadership only provided the 'idea' of an independent Indonesia. ${ }^{36}$ Actors on the ground everywhere created realities that were essentially local affairs (Kahin 1985:281). This was true in Kupang as well. But whereas Padang in West Sumatra, a town of around 80,000 with a strong political structure, managed for two years to prevent the Dutch from re-establishing control after World War II and developed a vibrant local democracy that also delivered many national leaders (Asnan 2007, Colombijn 1994:48), Kupang was at this time too small to do more than look on warily as distant powers sent garrison troops to ensure quiescence. Every central state in the twentieth century has relied on this small group of technical experts to manage the provinces. President Suharto's authoritarian New Order (1966-1998) was no different. His political party Golkar continues to do well in provincial Indonesia by dispensing patronage to locally influential bureaucrats, while doing its best to depoliticize the rest (which in the past often involved coercive threats). In the more democratic times that prevailed before and after the New Order, bureaucratic brokers were able to build up local resources that they could deploy against the centre to squeeze out concessions. This helps explain the emergence of more or less chauvinist localist movements in the towns at these times. Both Indonesia's ramshackle authoritarianism and its communalism have their origins in the spatiality of power.

\footnotetext{
36 What that 'idea' was has been well described by Elson (2008).
} 
As we shall see in subsequent chapters, there is more to Middle Indonesia than small town factionalism and the arrogance of technical elites. Over time, the flow of resources between the region and the metropolis via the town increased so as to reduce the role for 'gatekeeper' liaison brokers. Leftist movements from the metropolis in the early $1960 \mathrm{~s}$ encouraged and protected emancipatory movements that built crossclass, urban-rural alliances. On the right, New Order economic development caused the town and its middle class to outgrow the need for brokers. Kupang's eastern Indonesia and Jakarta's central Indonesia have grown closer. The rising number of substantial towns in eastern Indonesia confirms this observation (see Table 1 in Chapter 1). A similar slow growth of national networks at the expense of local ones was recorded by, for example, Washbrook (1976) in his careful history of the emergence of provincial politics in Madras between 1870 and 1920. Within Indonesia, Mestika Zed (1991) observed a similar process in the history of Palembang, a town in southern Sumatra. Here we have confined ourselves to the beginnings of this story, which lay with that tiny number of well-dressed local brokers. These unheroic 'jacks of all trades' made their little towns legible to their confused and technically challenged metropolitan masters, and brought new ideas, money and jobs to their educated fellow townsfolk. But they left their own poor powerless. 